\title{
Robert Ginsburg: Global Sedimentologist
}

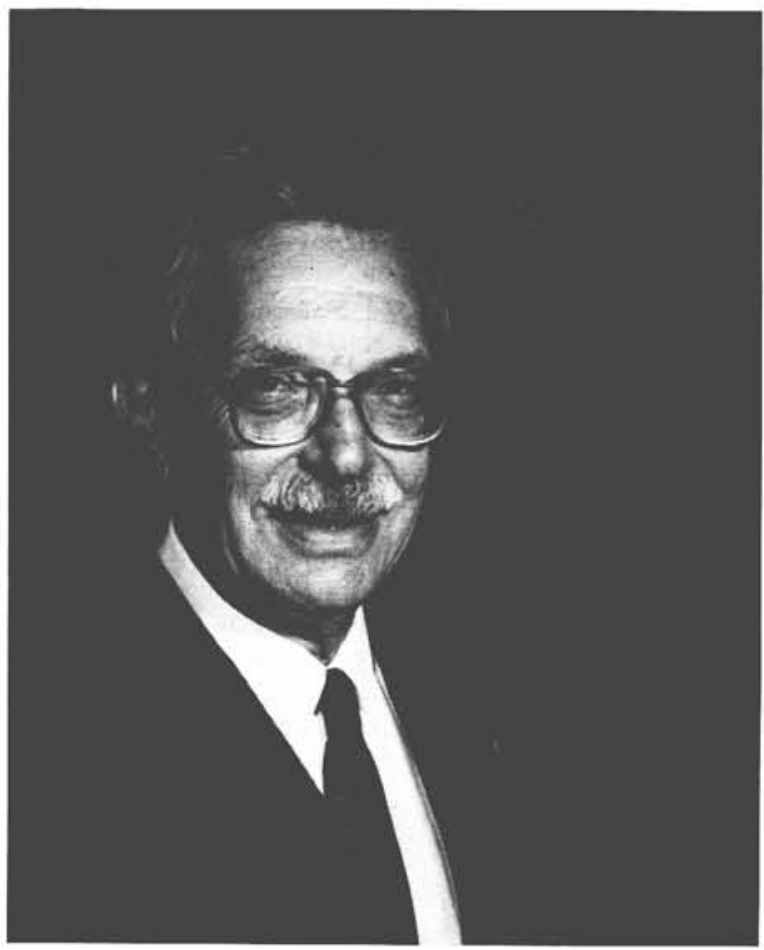

Professor Robert Ginsburg is the Chairman of IUGS's newest body, its Commission on Global Sedimentary Geology, and the moving force behind the rapidly growing international program on the same topic. Few individuals have influenced the course of carbonate geology more over the past thirty years, as attested by the citation for the 1985 Twenhofel Medal of the Society of Economic Paleontologists and Mineralogists (SEPM), "in recognition of pioneering and continuing research in comparative carbonate sedimentology, enduring leadership and the rare gift of stimulating those around him to excellence." Episodes caught up with Bob Ginsburg recently in his office at the University of Miami where he has been a Professor since 1970.

Episodes: How did you get started in geology, and who were early influences on your career?

Ginsburg: "I grew up around geology, as my father was an independent oil man in Texas and southern Illinois. There was always lots of talk about oil and sandstone reservoirs. There were maps, and there were numerous visits to wildcats in the piney woods of East Texas and the plains of southern Illinois. I can still remember driving with my father through forests of oil derricks in the boom towns of East Texas. Later I joined the Boy Scouts, got hooked on the out-of-doors and worked my way through all those merit badges to the Eagle rank.

"I began college in Texas, planning to be a petroleum engineer, but was attracted more to geology from my first course with a crusty, elderly field geologist named Charles Lawrence Baker who asked penetrating questions. Then came World War II and three years in the Corps of Engi- neers, winding up in the Philippines helping to fabricate landing craft for what was to have been the invasion of Japan. After the War, I went off to France to learn French, then back to the University of Illinois, and later to the University of Chicago.

"In the summer of 1948, I took the Chicago field camp at Baraboo, Wisconsin, taught by Jack Hough, then a marine geologist at Ilinois. He took us to the outcrops and left us alone to work out the structure, glacial history, or sedimentary environments, and to write it up or make maps. It was memorable, and I knew then I had made the right choice.

"In my two years at Chicago, there were three professors who influenced my development. From Francis Pettijohn I learned to ask critical questions about observations and interpretations, my own as well as those of others. From Robert Balk I realized how much one could learn from rocks in the field. Heinz Lowenstam inspired me and other students with an interest in organisms, their remains and effects on sedimentary deposits. Chicago at that time was a most exciting place. Harold Urey and his students were developing stable isotope thermometry; Willard Libby was establishing radiocarbon dating, and Hans Ramberg was applying thermodynamics to metamorphic rocks. Add to all this, a group of outstanding, committed fellow students who almost to a man were in their offices or the library until near midnight most nights of the week."

What drew you to sediments and especially to carbonates?

"I was drawn to sedimentary deposits from my connections with the oil business and my love affair with the out-ofdoors. In Pettijohn's course I was captivated by learning how much could be deduced from a paper-thin slice of rock. Lowenstam showed me and my fellow students how much fossils could tell about environments, and he introduced us to the romance of reefs.

From 1954 to 1965 following his doctoral studies at Chicago, Prof. Ginsburg was a research geologist with Shell. As he says: "I was lucky to have worked in industry at a time when there was complete freedom to tackle basic questions. Two of the major advantages of my tenure with industry were that it gave me a strong orientation towards the threedimensional geometry of sedimentary deposits, and the realization of the need to predict, both for practical purposes as well as a test of the depths of understanding. Here again, I was lucky to have outstanding colleagues and associates many of whom are now leaders in academic institutions here and abroad."

"I left Chicago eager for romance and adventure overseas, but when I could not find a job in industry, I took a Research Assistant post at the University of Miami's Marine Laboratory and became their first geologist. And there I was surrounded by carbonates!"

And what about the Global Sedimentary Geology Program (GSGP)? How did it start?

"A combination of circumstances and thinking led to GSGP. First, and probably most important, was my involvement with the IUGS Committee on Sedimentology at the Moscow Congress. There Keith Crook and I worked to develop plans for a Commission on Sedimentology, but we were unable to find a theme or focus. Then back home, I realized that 
some new directions in science are energized when they participate in what I refer to as the "temper of the times." For example, I believe that oceanography got its start in the 19 th century riding on world interest in the oceans sparked by the development of submarine telegraphy; sedimentology and stratigraphy came of age following World War I when there was a major expansion of the petroleum industry and its exploration. With those examples to guide me, it is not difficult to see how I concluded that the "temper of the times" is global, and that world spirit made consideration of global-scale questions appropriate, just as colleagues in plate tectonics and paleo-oceanography were doing.

"When I first proposed the idea of an international program in sedimentary geology, the then-president of SEPlil, Orrin Pilkey, thought it was just what our specialty needed. The councils of $3 \mathrm{EPM}$ and IAS (The International Association of Sedimentology) both agreed, as did Keith Crook. SEPM and IAS gave the idea their full support even though it was clear from the outset that neither would be able to organize and run such a program.

"In my view the goals of GSGP are to foster global-scale thinking about sedimentary deposits and processes responsible for them, to improve the practice of our specialty, and to expand international communication. The Program Development Committee has selected an initial research project on the Cretaceous as a way to achieve these goals.
Furthermore, the project has a high GARLIC quotient: G for global in scope; A for arresting; $R$ for relevant to human needs; L for leadership; I for innovative; and $C$ for a community of workers to accomplish the objectives.

"Our first major challenge is to organize working groups that can identify research objectives for the Cretaceous Project, inspire and train colleagues to work on the objectives, and gain the necessary support and cooperation of industry, government, and academia. For example, to test the idea of globally synchronous fluctuations in sea level, we need to ask our Geochronology Committee to select recognizeable time slices, then train colleagues to read the sedimentary signatures of sea level, and finally to coordinate, compile, and analyze their observations. And sea level fluctuations are only one of the five topics we plan to research. Challenging indeed!"

Clearly, Bob Ginsburg is well qualified to lead the GSGP. His wide experience, his record of excellence in research, and his extensive involvement as member and officer of many societies, including SEPM (President, 1969) and IAS (current Vice-President), also bear witness to this. IUGS is indeed fortunate to have Prof. Ginsburg chair its new commission. $\square$

"Geology, above all in the sciences, demands clarity of language and a thoroughly international approach. We must all be very grateful for this substantial compilation which breaks through the language barrier.'

C.H. Holland, Department of Geology. Trinity College. Dublin. Ireland

\section{MULTILINGUAL THESAURUS OF GEOSCIENCES English French German Russian Spanish Italian Edited by}

G. N. Rassam, COGEODOC, American Geological Institute, Alexandria, VA, USA

\section{J. Gravesteijn, COGEODOC,}

Bureau de Recherches Geologiques et Minieres, Orleans, France

\section{R. Potenza, COGEODOC,} Consiglio Nazionale di Richerche, Milan, Italy
"This is an outstanding international undertaking, contributing to the worldwide community of Geosciences. This thesaurus will not only serve translators but scientists, students, teachers, librarians, and industrial workers will also find it useful as a handbook."

Kozo Takahashi, Ph.D., Associate Scientist

Woods Hole Oceanographic Institution, Woods Hole, Massachusetts

"With publication of this thesaurus, the aim of the project to 'facilitate the exchange of bibliographic data between the different organizations and linguistic groups through an international network of documentation for the benefit of all geologists' is achieved admirably." Daniel F. Merriam, Endowment Association Distinguished Professor of the Natural Sciences and Chairman, Department of Geology, Wichita State University, Wichita, Kansas

"Our sincere thanks to the editors and to Pergamon Press for having published such an important working tool."

Dr. Bermuco Melendez, Lecturer of Paleontology

Faculty of Geological Sciences, University Complutense, Madrid, Spain

Contents: An historical introduction to the development of the thesaurus is presented followed by an explanation of the technical methodology used in its preparation. The body consists of alphabetical key entries in English followed by translations in five languages. The body also includes the field of geosciences to which the term belongs as well as a "use" indicator. Finally, indexes are compiled for each language.

March 1987

ISBN (H) 0080364314

US $\$ 120.00$

600 pages

US: Maxwell House, Fairview Park, Elmsford, NY 10523 (914) 592-7700 